\title{
Investigation of Factors Facilitating the Happiness of Individuals Participating in Leisure Activities
}

\author{
Veli Ozan Çakır (Corresponding author) \\ Faculty of Sports Sciences \\ Alanya Alaaddin Keykubat University, Antalya, Turkey \\ E-mail: veliozancakir@gmail.com
}

Received: July 30, 2021 Accepted: August 27, 2021 Published: September 8, 2021

doi:10.5296/jei.v7i2.18895 URL: https://doi.org/10.5296/jei.v7i2.18895

\begin{abstract}
This study aimed to examine the factors that facilitate happiness in leisure. The research was performed according to the relational screening design, one of the scanning models. A total of 260 students, 180 male and 80 female, selected by simple random sampling method, studying at Istanbul University-Cerrahpaşa Faculty of Sport Sciences participated in the research group. In addition to the personal information form to collect data in the study, the Oxford Happiness Scale-Short Form (OHS-S) developed by Hills and Argyle (2002) and adapted into Turkish by Doğan and Çötok (2011), and the Leisure Facilitators Scale (LFS) developed by Kim et al. (2011) and adapted into Turkish by Gurbuz et al. (2015) were used as data collection tools. Considering the skewness and kurtosis values of the research data, it was accepted that the data showed a normal distribution. Moreover, t-test, ANOVA and Pearson Correlation test were used in the analysis. In this context, while no significant difference was found between the happiness of individuals according to their gender, a significant difference was determined between leisure facilitators. Moreover, a moderately significant relationship was found between leisure facilitators and happiness. As a result, personal, interpersonal and structural facilitators were identified as factors that facilitate the happiness of individuals in their leisure.
\end{abstract}

Keywords: Leisure, Leisure Facilitators, Happiness

\section{Introduction}

In the recent years, the developments in science and technology in modern life (Avunduk, 2021a) causes less need for people's labour while at the same time reducing their working hours. While workers working between 3500 and 4000 hours at the beginning of the Industrial Revolution, this number decreases to less than 1800 hours today. In other words, 
weekly working hours are reduced from 80 hours to less than 40 hours, and this means that people's leisure increased in parallel (Arslan, 2013). Regarding this situation, Jensen and Naylor (2005) state that the length of vacation time, the convenience of people in working conditions, and people have more leisure compared to other periods in history. It is seen that in the age we live in, especially in industrialized countries, developing and traditional societies are aware of the increase in the leisure periods (Karaküçük, 2014). Because leisure is like a symbol of development and modern life (Kelly, 1990).

While leisure is defined as the period that includes activities that people can participate in voluntarily (Daniel et al., 2008), this period is an important factor in people's sense of success and pleasure (Chen et al., 2013). Therefore, in recent years, researchers have drawn their attention to this point in the study of leisure. Because leisure has turned into a period that attracts more and more attention in contemporary societies and the usage of leisure became an important situation for people (Hou, 2003). The usage of leisure efficiently is important for people to get away from stress and to be more successful in their social and personal lives (Türker et al., 2016). While the use of leisure differs from society to society, culture to culture and even from individual to individual, the meaning attributed to leisure activities and the expected output from activities may also differ. The only thing that does not change for the people who participate (Gökçe, 2020) is the aim of getting satisfaction from these activities (Mannel \& Kleiber, 1999). Researches show that; The satisfaction that people get from leisure activities affects their personality and mental states positively (Liu, 2014; Yağar \& Yerlisu Lapa, 2015), mediating a life without depression (Chang et al., 2018) and happy (Öztaş, 2018) can increase satisfaction (Köksal, 2019). While the importance of leisure periods that people have and their positive evaluation is extremely important; researchers have revealed the need to examine the factors that facilitate people's participation in leisure activities. While Raymore (2002) states that the factors that facilitate people's participation in leisure activities should be known; Beşikçi (2020) states that knowing these factors is important for encouraging people to participate in leisure activities and ensure continuity in participation. Researchers are group leisure facilitators by use of the leisure barrier theory. In this context, it is thought that examined from three different perspectives as individual facilitators, interpersonal facilitators, and structural facilitators can be a better perspective (Sarol, 2017). Individual facilitators are defining as the skills, characteristics and beliefs that the individual develops in line with his/her area of interest (Beşikçi, 2020). Interpersonal facilitators have a developing quality in choosing and participating in leisure activities (Beşikçi, 2020) such as family members, friends, club membership (Sarol, 2017). Structural facilitators can be explained as factors such as money, ethnicity, gender, socio-economic status (Swinton et al., 2008). It is thought that knowing these facilitating factors in participation in leisure activities is important at the stage of people's participation in leisure activities (Gürbüz et al., 2015).

Happiness is a situation that is emphasized, tried to be understood and defined together with the history of humanity (Mumcu, 2019). Considering at the concept of happiness, which aims to make life meaningful, has continued to develop day by day (Lyubomirsky, 2007) and is become a concept that is considered, evaluated and policies are developing in almost every 
country and society (Korkut, 2019). Because happiness can be expressed as the degree to which individuals evaluated their quality of life (Selim, 2008). Although there are many factors for happiness in many areas of life, it is a fact that there are also intermediary reasons to increase happiness. It is demonstrated by scientific studies that people are happy, especially with sports activities. In addition, it is determined by scientific studies that individuals' recreational activities in their leisure (Alanoğlu, 2020), the freedom they perceive in their leisure (Siyahtaş \& Ertekin, 2020) and the satisfaction obtained in the leisure activities that individuals participate in increase their happiness (Öztaş, 2018). Therefore, these activities are of great importance for the happiness of the individual (Avunduk, 2021b). Therefore, it is thought that it is important to investigate which facilitating factors affect the happiness of individuals in leisure activities and to contribute to the literature. In this context, the main aim of this research is to examine the factors that facilitate the happiness of individuals in leisure activities; At the same time, it is to determine whether the gender of individuals affects their happiness levels and leisure facilitators.

\section{Method}

\subsection{Research Model}

This research was performed according to the screening model, which is one of the quantitative research methods. One of the screening models was applied according to the relational scanning design. Relational screening design is a research design that aims to determine the existence or degree of change between two or more variables (Karasar, 2020).

\subsection{Research Group}

A total of 260 students, 180 male and 80 female, selected by simple random sampling method, studying at Istanbul University-Cerrahpaşa Faculty of Sport Sciences, participated in the study group of the research.

\subsection{Data Collection Tools}

\subsubsection{Personal Information Form}

To determine the variables such as gender and age of the individuals participating in the research, the "Personal Information Form" prepared by the researcher was used.

\subsubsection{Oxford Happiness Scale-Short Form (OHS-S)}

OHS-S was developed by Hills and Argyle (2002), and adapted into Turkish by Doğan and Çötok (2011). The scale consisted of a 5-point Likert type (1-strongly disagree, 5-strongly agree), and 7 items and a single factor. The reliability coefficient of the scale was determined as 0.85 , and the internal consistency coefficient determined for this study was 0.79 .

\subsubsection{Leisure Facilitators Scale (LFS)}

LFS was developed by Kim et al. (2011) and Gurbuz et al. (2015) adapted into Turkish. LFS consisted of 16 items in 5-point Likert type (1-not important, 5-very important) and 3 sub-dimensions (personal facilitators, interpersonal facilitators, structural facilitators). The 


\section{Mll Macrothink}

Cronbach Alpha value calculated for the total of the scale was determined as 0.86 , and for this study it was determined as 0.82 .

\subsection{Analysis of Data}

SPSS 20.0 package program was used in the analysis of the research data. Percentage (\%) and frequency (f) methods were used in the distribution of personal data of individuals participating in the research. Whether the research data showed a normal distribution or not was understood by the skewness and kurtosis values. According to Büyüköztürk (2014), the fact that the data were in the range of $-1,+1$ can be interpreted as the scores did not show a significant deviation from the normal distribution. Therefore, as shown in Table 2, since the research data were in the range of $-1,+1$, it was accepted that the data showed a normal distribution. After the data showed normal distribution, independent samples t-test was used in the analyzes and Pearson Correlation test was used to determine the relationship between the variables. Evaluation of the data took place at the $95 \%$ confidence interval.

\section{Results}

Table 1. Distribution of demographic characteristics of individuals

\begin{tabular}{|l|l|l|l|}
\hline & & $\mathbf{f}$ & $\mathbf{\%}$ \\
\hline \multirow{5}{*}{ Gender } & Male & 180 & 69.6 \\
\cline { 2 - 4 } Age & Female & 80 & 30.4 \\
\cline { 2 - 4 } & Total & $\mathbf{2 6 0}$ & $\mathbf{1 0 0 . 0}$ \\
\hline \multirow{5}{*}{ Welfare Status } & $18-21$ & 103 & 39.6 \\
\cline { 2 - 4 } & $22-25$ & 120 & 46.2 \\
\cline { 2 - 4 } & 26 and older & 37 & 14.2 \\
\cline { 2 - 4 } & Total & $\mathbf{2 6 0}$ & $\mathbf{1 0 0 . 0}$ \\
\hline & Low & 118 & 45.4 \\
\cline { 2 - 4 } & Normal & 78 & 30.0 \\
\cline { 2 - 4 } & High & 64 & 24.6 \\
\cline { 2 - 4 } & Total & $\mathbf{2 6 0}$ & $\mathbf{1 0 0 . 0}$ \\
\hline
\end{tabular}

Table 1 showed the distribution of the demographic characteristics of the individuals participating in the research. According to the table, it was determined that $69.6 \%$ of the participants were "male" and $30.4 \%$ were "female". It was determined that $39.6 \%$ of the individuals in the study were in the "18-21 age group", $46.2 \%$ were in the " $22-25$ age group" and $14.2 \%$ were " 26 years old and over". It was determined that the welfare level of $45.4 \%$ of the individuals participating in the research was "low", $30.0 \%$ "normal" and $24.6 \%$ "high". 
Table 2. Distribution of scale scores

\begin{tabular}{|l|l|l|l|l|l|l|l|}
\hline \multicolumn{2}{|l|}{ Sub-dimensions } & Item Number & $\mathbf{n}$ & Mean & Sd. & Skewness & Kurtosis \\
\hline Oxford Happiness Scale & Happiness & 7 & 260 & 2.93 & .55 & .457 & .561 \\
\hline Leisure Facilitators Scale & & & & & & & \\
\hline & Personal facilitators & 5 & 260 & 3.53 & .92 & -.599 & .463 \\
\hline & Interpersonal facilitators & 4 & 260 & 3.41 & .84 & -.455 & .581 \\
\hline & Structural facilitators & 7 & 260 & 3.57 & .88 & -.741 & .458 \\
\hline
\end{tabular}

Table 2 showed the score distribution of the sub-dimensions of the scale obtained from the individuals participating in the research. According to the table, it was determined that the mean obtained by the individuals from the happiness scale was 2.93. It was determined that individuals have mean of 3.53 for the "personal facilitators" sub-dimension, 3.41 for the "interpersonal facilitators" sub-dimension, and 3.57 for the "structural facilitators" sub-dimensions of the Leisure Facilitators Scale.

Table 3. Results of analysis between happiness and sub-dimensions of LFS by gender

\begin{tabular}{|c|c|c|c|c|c|c|}
\hline Scales & Sub-dimensions & Gender & $\mathbf{n}$ & Mean \pm Ss & t & $\mathbf{p}$ \\
\hline \multirow{2}{*}{ Oxford Happiness Scale } & \multirow{2}{*}{ Happiness } & Male & 180 & $2.92 \pm 0.60$ & \multirow{2}{*}{1.557} & \multirow{2}{*}{.184} \\
\hline & & Female & 80 & $2.96 \pm 0.43$ & & \\
\hline \multirow{6}{*}{ Leisure Facilitators Scale } & \multirow{2}{*}{ Personal facilitators } & Male & 180 & $3.51 \pm 0.98$ & \multirow{2}{*}{1.268} & \multirow{2}{*}{.226} \\
\hline & & Female & 80 & $3.57 \pm 0.78$ & & \\
\hline & \multirow{2}{*}{ Interpersonal facilitators } & Male & 180 & $3.42 \pm 0.87$ & \multirow{2}{*}{.985} & \multirow{2}{*}{.354} \\
\hline & & Female & 80 & $3.37 \pm 0.75$ & & \\
\hline & \multirow{2}{*}{ Structural facilitators } & Male & 180 & $3.56 \pm 0.93$ & \multirow{2}{*}{6.851} & \multirow{2}{*}{.000} \\
\hline & & Female & 80 & $3.60 \pm 0.77$ & & \\
\hline
\end{tabular}

Table 3 showed the results of the independent samples t-test between the sub-dimensions of the happiness and leisure facilitators scale according to the gender variables of the individuals participating in the research. In the analysis results, no statistically significant difference was found between the happiness of individuals according to their gender $(p>0.05)$.

Another result of the research analyzes was that while there was no statistically significant difference between the sub-dimensions of LFS "personal facilitators" and "interpersonal 


\section{Ml Macrothink}

facilitators" according to the gender variables of the individuals $(p>0.05)$, a significant difference was found between the "structural facilitators" sub-dimension $(p<0.05)$.

Table 4. ANOVA results on scale scores according to the welfare status variable

\begin{tabular}{|c|c|c|c|c|c|c|}
\hline Scales & Sub-dimensions & Welfare Status & $\mathbf{n}$ & $\operatorname{Mean} \pm$ Ss & f & $\mathbf{p}$ \\
\hline \multirow{3}{*}{ Oxford Happiness Scale } & \multirow{3}{*}{ Happiness } & Low & 118 & $1.98 \pm 0.79$ & \multirow{3}{*}{8.267} & \multirow{3}{*}{$.000^{*}$} \\
\hline & & Normal & 78 & $2.03 \pm 0.45$ & & \\
\hline & & High & 64 & $2.47 \pm 0.81$ & & \\
\hline \multirow{9}{*}{ Leisure Facilitators Scale } & \multirow{3}{*}{ Personal facilitators } & Low & 118 & $2.01 \pm 0.88$ & \multirow{3}{*}{.352} & \multirow{3}{*}{.322} \\
\hline & & Normal & 78 & $2.06 \pm 0.71$ & & \\
\hline & & High & 64 & $2.85 \pm 0.82$ & & \\
\hline & \multirow{3}{*}{ Interpersonal facilitators } & Low & 118 & $2.93 \pm 0.80$ & \multirow{3}{*}{.257} & \multirow{3}{*}{.527} \\
\hline & & Normal & 78 & $3.05 \pm 0.71$ & & \\
\hline & & High & 64 & $3.17 \pm 0.74$ & & \\
\hline & \multirow{3}{*}{ Structural facilitators } & Low & 118 & $2.85 \pm 0.77$ & \multirow{3}{*}{6.725} & \multirow{3}{*}{$.000 *$} \\
\hline & & Normal & 78 & $3.05 \pm 0.56$ & & \\
\hline & & High & 64 & $3.25 \pm 0.69$ & & \\
\hline
\end{tabular}

In Table 4, the results of ANOVA analysis regarding the scale scores according to the welfare status of the individuals participating in the research were given. According to the analysis results, A significant difference was found between the happiness of individuals according to their welfare status $(p<0.05)$. It was determined that the significant difference was in favor of individuals with a high level of welfare.

When the table is examined; While no significant difference was found between LFS "personal facilitators" and "interpersonal facilitators" according to the welfare status of individuals $(\mathrm{p}>0.05)$; A significant difference was found between "structural facilitators" ( $\mathrm{p}$ $<0.05$ ). In the structural facilitators sub-dimension, it was determined that the average of individuals with high welfare status was higher than those with normal and low levels. 
Table 5. Correlation results between LFS sub-dimensions and happiness

\begin{tabular}{|l|l|}
\hline & Happiness \\
\hline Personal facilitators & $\mathbf{. 3 0 7 *}$ \\
\hline Interpersonal facilitators & $.324^{*}$ \\
\hline Structural facilitators & $.274^{*}$ \\
\hline
\end{tabular}

Table 5 showed the correlation results between the sub-dimensions of LFS and happiness. In the analysis results, a positive correlation was found between "personal facilitators" and "happiness" ( $\mathrm{r}=.30 ; \mathrm{p}<0.05)$, and a moderate positive correlation between "interpersonal facilitators" and "happiness" $(\mathrm{r}=.32 ; \mathrm{p}<0.059)$. Moreover, a moderate positive correlation was found between "structural facilitators" and "happiness" $(r=.27 ; p<0.05)$.

\section{Discussion and Conclusion}

The main aim of this research was to examine the factors that facilitate the happiness of individuals in leisure activities. In addition, it was to determine whether there was a significant difference between the genders of individuals in terms of happiness levels and leisure facilitators.

According to the results; Although female individuals mean score of happiness (2.96) were higher than the mean score of male individuals (2.92), the mean score of happiness was not found statistically significant. Many studies were found in the literature examining the relationship between happiness and different concepts. Studies conducted were showed that the majority of studies showing that the gender of individuals did not affect happiness. For examaple Demir and Murat (2017), Saygin and Arslan (2009), Eryılmaz and Aypay (2011), Toprak (2014), Şahin (2015), Demirel (2019), Serdar (2020), Serdar et al. (2018) and Aydın (2016) concluded that gender does not affect happiness. Therefore, the results of this study and the results of the studies conducted were showed parallelism. However, there were also studies found in which a significant difference was found between happiness by gender. In the studies conducted by Gülcan (2014), Şaşmaz (2016), and Wei et al. (2015), it was concluded that the level of happiness differs according to gender. Since happiness was a relative concept against changing situations and events, and it was parallel to the living conditions of the day, it was thought that the differences emerging in the researches were natural. While there was not any statistically significant difference was found between the "personal facilitators" and "interpersonal facilitators" sub-dimensions of leisure facilitators according to the gender of the individuals; There was a significant difference between the "structural facilitators" according to the gender of the individuals. When the mean scores of the genders in the structural facilitators sub-dimension were examined, it was seen that the mean scores of female individuals were higher than the mean scores of male individuals. In the studies conducted by Bilgili (2019), Sarol (2017), Siyahtaş et al. (2018), and Özkan (2018), significant differences were found between the structural facilitators according to the gender of the individuals. Therefore, the results of this study and the results of the studies 
conducted showed parallelism. In the research findings, a significant difference was found between the happiness of individuals according to their welfare level. It can be said that individuals who state their level of well-being as high are happier than those who state it as normal and bad. In the study conducted by Serdar (2020), it was seen that the same result was reached. Therefore, it can be said that the effect of high welfare levels on the happiness of individuals is important. When the effect of the welfare level of individuals on the leisure facilitating factors is examined in the research findings, it has been determined that the welfare level has a significant effect on the structural facilitating factors.

The main aim of the research was to examine the factors that facilitate the happiness of individuals in leisure. In the analysis results; A positive and moderately significant relationship was found between the happiness of individuals and the sub-dimensions of leisure facilitators. In other words, it was concluded that as individuals' personal facilitators, interpersonal facilitators and structural facilitators increase, their happiness would also increase. In other words; It can be said that all factors, including personal, interpersonal and structural factors, facilitate the happiness of individuals in their leisure.

\section{References}

Alanoğlu, Ş. (2020). Düzenli rekreasyonel aktivitelerin yetişkin kadınların stres, mutluluk ve yaşam tatminleri üzerine etkisi (Yüksek Lisans Tezi, Sakarya Uygulamalı Bilimler Üniversitesi Lisansüstü Eğitim Enstitüsü Beden Eğitimi ve Spor Öğretmenliği Anabilim Dalı. Sakarya).

Arslan, S. (2013). Serbest zaman-Rekreasyon ve serbest zaman eğitimi. Nobel Akademik Yayıncilik, Ankara.

Avunduk, Y. (2021a). The relationship between leisure satisfaction and hopelessness. International Journal of Applied Exercise Physiology, 10(1), 6-11.

Avunduk, Y. (2021b). The relationship between leisure satisfaction and social media addictions of individuals at university. Journal of Educational Issues, 7(1), 507-522. https://doi.org/10.5296/jei.v7i1.18592

Aydın, İ. (2016). Fitness katılımcllarının rekreasyonel etkinliklere yönelik ılgilenim ve mutluluk düzeylerinin belirlenmesi. Gazi Üniversitesi Sağlık Bilimleri Enstitüsü.

Beşikçi, T. (2020). Üniversite kampüslerinde rekreasyon uygulamalarının serbest zaman engelleri, kolaylaştırıcıları ve doyumu üzerine etkileri (Doktora Tezi, Manisa Celal Bayar Üniversitesi Sağlık Bilimleri Enstitüsü. Beden Eğitimi ve Spor Anabilim Dalı. Manisa).

Bilgili, Ö. (2019). Akademik personellerin serbest zaman faaliyetlerindeki kolaylaştırıcıları ile motivasyon düzeyleri arasındaki ilişkinin incelenmesi (Yüksek Lisans Tezi, Bartın Üniversitesi Eğitim Bilimleri ve Spor Öğretimi Anabilim Dalı Beden Eğitimi ve Spor Eğitimi Bilim Dal1).

Büyüköztürk, Ş. (2014). Sosyal bilimler için veri analizi el kitabı. Ankara: Pegem Akademi.

Chang, P., Lin, Y., \& Song, R. (2018). Leisure Satisfaction Mediates the Relationships 
between Leisure Settings, Subjective Well-Being, and Depression among Middle-Aged Adults in Urban China. Springer Nature and the International Society for Quality of-Life Studies, 14(1), 1001-1017. https://doi.org/10.1007/s11482-018-9630-3

Chen, Y. C., Li, R. H., \& Chen, S. H. (2013). Relationships Among Adolescents' Leisure Motivation, Leisure Involvement, and Leisure Satisfaction: A Structural Equation Model. Social Indicatiors Research, 110(3), 1187-1199. https://doi.org/10.1007/s11205-011-9979-2

Daniel, D. M., Army, R. H., \& Nancy, B. R. (2008). Kraus' Recreation and Leisure in Modern Society (8th ed.). Jones and Barlett Publishers: Boston.

Demir, R., \& Murat, M. (2017). Öğretmen Adaylarının Mutluluk, İyimserlik, Yaşam Anlamı ve Yaşam Doyumlarının İncelenmesi. OPUS Uluslararası Toplum Araştırmaları Dergisi, 7(13), 348-378. https://doi.org/10.26466/opus.347656

Demirel, M. (2019). Leisure involvement and happiness levels of individuals having fitness center membership. Journal of Education and Learning, 8(6), 140-149. https://doi.org/ 10.5539/jel.v8n6p140

Doğan, T., \& Çötok, N. A. (2011). Oxford mutluluk ölçeği kısa formunun türkçe uyarlaması geçerlik ve güvenirlik çalışması. Türk Psikolojik Danışma ve Rehberlik Dergisi, 4(36), 165-172.

Eryılmaz, A., \& Aypay, A. (2011). Ergen öznel iyi oluşu ile kimlik statüsü ilişkisinin incelenmesi. Dicle Üniversitesi Ziya Gökalp Eğitim Fakültesi Dergisi, 16, 167-179.

Gökçe, H. (2020). Rekreasyon ve yerel yönetimler. Pegem Akademi, Ankara. https://doi.org/ $10.14527 / 9786257880268$

Gülcan, A. (2014). Genç yetişkinlerde iyimserliğin mutluluk ve yaşam doyumu üzerindeki etkisinin incelenmesi (Yüksek Lisans Tezi, Fatih Üniversitesi Sosyal Bilimler Enstitüsü).

Gürbüz, B, Öncü, E., \& Emir, E. (2015). Serbest Zaman Kolaylaştırıcıları Ölçeğinin Türkçeye Uyarlanması: Geçerlik ve Güvenirlik Çalışması. 3 Rekreasyon Araştırmaları Kongresi. https://doi.org/10.16991/INESJOURNAL.29

Hills, P., \& Argyle, M. (2002). The oxford happiness questionnaire: a compact scale for the measurement of psychological well-being. Personality and Individual Differences, 33, 1073-1082. https://doi.org/10.1016/S0191-8869(01)00213-6

Hou, Y.-H. (2003). Taiwanese college students and lesiure: The relationship between their leisure motivations and leisure constraints (Ph.D. Dissertation, Spalding University).

Jensen, C., \& Naylor, J. (2005). Opportunities in Recreation and Leisure Careers. Illinois: Vgm Career Horizon.

Karaküçük, S. (2014). Rekreasyon Boş Zamanları Değerlendirme. Gazi Kitabevi, Ankara.

Karasar, N. (2020). Bilimsel Araştırma Yöntemi. Kavramlar, Ilkeler ve Teknikler. Nobel Akademi. 
Kelly, J. R. (1990). Leisure (p. 440). Prentice Hall, Englewood Clieffs, New Jersey.

Köksal, G. (2019). Serbest zaman doyumu ve yaşam tatmini ilişkisi: beden eğitimi ögretmenleri örneği (Yüksek Lisans Tezi, Selçuk Üniversitesi Sağlık Bilimleri Enstitüsü Spor Yöneticiliği Anabilim Dalı. Konya).

Korkut, A. (2019). Öğretmenlerin örgütsel mutluluk, örgütsel sinizm, ve örgütsel adalet algılarının analizi (Doktora Tezi, İnönü Üniversitesi Eğitim Bilimleri Enstitüsü Eğitim bilimleri Anabilim Dalı Eğitim Yönetimi bilim Dalı. Malatya).

Liu, H. (2014). Personality, leisure satisfaction, and subjective well-being of serious leisure participants. Social Behavior and Personality, 42(7), 1117-1126. https://doi.org/10.2224/ sbp.2014.42.7.1117

Lyubomirsky, S. (2007). Nasıl mutlu olunur. İstanbul: Mediacat Kitapları.

Mannel, R. C., \& Kleiber, D. A. (1999). A social psychology of leisure. State College, PA: Venture Publishing.

Mumcu, N. (2019). Aktif spor yapan ve yapmayan beden ĕgitimi öğrencilerinin stres ve mutluluk düzeylerinin belirlenmesi (Yüksek Lisans Tezi, Hitit Üniversitesi Sağlık Bilimleri Enstitüsü Beden Eğitimi ve Spor Anabilim Dalı. Çorum).

Özkan, S. (2018). Kamu personelinin serbest zaman etkinliklerine katılımlarına engel teşkil eden faktörler ile serbest zaman etkinliklerine katılımı kolaylaştıran faktörlerin incelenmesi (Yüksek Lisans Tezi, Dumlupınar Üniversitesi. Sağlık Bilimleri Enstitüsü Beden Eğitimi ve Spor Anabilim Dali).

Öztaş, İ. (2018). Farklı kurumlarda çalışan memurların serbest zaman doyum ve mutluluk düzeylerinin belirlenmesi (Kırlkkale ili örneği) (Yüksek Lisans Tezi, Ağrı İbrahim Çeçen Üniversitesi Sosyal Bilimler Enstitüsü Beden Eğitimi ve Spor Anabilim Dalı. Ağrı).

Raymore, L. A. (2002). Facilitators to Leisere. Journal of Leisure Research, 34(1), 37-51. https://doi.org/10.1080/00222216.2002.11949959

Şahin, Y. (2015). Üniversite ögrencilerinin mutluluk, iyimserlik ve özgecilik düzeylerinin incelenmesi (Yayımlanmamış Yüksek Lisans Tezi, Gaziosmanpaşa Üniversitesi Eğitim Bilimleri Enstitüsü).

Sarol, H. (2017). Bireylerin fiziksel aktiviteye katılımını engelleyen ve kolaylaştıran faktörlerin belirlenmesi. International Journal of Human Sciences, 14(4), 4354-4364. https://doi.org/10.14687/jhs.v14i4.5121

Şaşmaz, Ş. C. (2016). Çocuğu olan evli ve evli olmayan bireylerin psikolojik sağlamlık ve mutluluk düzeylerinin incelenmesi (Yüksek Lisans Tezi, Beykent Üniversitesi Sosyal Bilimler Enstitüsü).

Saygın, Y., \& Arslan, C. (2009). Üniversite öğrencilerinin sosyal destek, benlik saygısı ve öznel iyi oluş düzeylerinin incelenmesi. Selçuk Üniversitesi Ahmet Keleşoğlu Ĕgitim Fakültesi Dergisi, 28, 207-222. 


\section{Macrothink

Selim, S. (2008). Türkiye'de bireysel mutluluk kaynağı olan değerler üzerine bir analiz: Multinomial logit model. Journal of the Cukurova University Institute of Social Sciences, 17(3).

Serdar, E. (2020). Serbest zaman fayda ile mutluluk arasındaki ilişki: Spor bilimleri fakültesi öğrencileri. Turkish Studies-Social, 15(5), 2711-2721. https://doi.org/10.47356/Turkish Studies.44273

Serdar, E., Demirel, M., Demirel, D. H., \& Donuk, B. (2018). Üniversite öğrencilerinin serbest zaman doyum düzeyleri ile mutluluk düzeyleri arasındaki ilişki. Sosyal Bilimler Dergisi, 5(28), 429-438. https://doi.org/10.16990/SOBIDER.4412

Siyahtaş, A., \& Ertekin, A. B. (2020). Üniversite ögrencilerinin serbest zamanlarda algıladıkları özgürlük düzeyleri ile mutluluk düzeyleri arasındaki ilişki. 18. Uluslararası Spor Bilimleri Kongresi, 07-09 Kasim 2020.

Siyahtaş, A., Tükenmez, A., Hocaoğlu, M., \& Donuk, B. (2018). Üniversitede öğrenim gören bireylerin serbest zaman engelleri ile kolaylaştırıcıları arasındaki ilişki. Journal of Social and Humanities Sciences Research, 5(24), 1795-1805. https://doi.org/10.26450/jshsr.553

Swinton, A. T., Freman, P. A., Zabriskie, R. B., \& Fields, P. J. (2008). Nonresident Fathers' Family Leisure Patterns during Parenting Time with Their Children. Fathering, 6(3), 205-225. https://doi.org/10.3149/fth.0603.205

Toprak, H. (2014). Ergenlerde mutluluk ve yaşam doyumunun yordayıcısı olarak psikolojik sağlamlık ve psikolojik ihtiyaç doyumu (Yüksek Lisans Tezi, Sakarya Üniversitesi Eğitim Bilimleri Enstitüsü).

Türker, N., Ölçer, H., \& Aydın, A. (2016). Yerel Halkın Serbest Zaman Değerlendirme Alışkanlıkları: Safranbolu Örneği. Karabük Üniversitesi Sosyal Bilimler Enstitüsü Dergisi, 6(1), 49-62. https://doi.org/10.14230/joiss230

Wei, X., Huang, S. S., Stodolska, M., \& Yu, Y. (2015). Leisure time, leisure activities, and happiness in China. Journal of Leisure Research, 47(5), 556-576. https://doi.org/10.18666/ jlr-2015-v47-i5-6120

Yağar, G., \& Yerlisu Lapa, T. (2015). The impact of personality traits on leisure and life satisfaction in women who participate in exercise. Pamukkale Journal of Sport Sciences, 6(2), 65-76.

\section{Copyright Disclaimer}

Copyright for this article is retained by the author(s), with first publication rights granted to the journal.

This is an open-access article distributed under the terms and conditions of the Creative Commons Attribution license (http://creativecommons.org/licenses/by/3.0/). 